\title{
EXPLORING THE POTENTIAL OF CULTURAL HISTORICAL ACTIVITY THEORY FOR UNDERSTANDING CHANGE IN EDUCATION: LESSONS FROM A HISTORICAL CASE STUDY OF LEADERSHIP IN AN IRISH SCHOOL
}

\author{
Explorando el potencial de la Teoría de la Actividad Histórico-
} Cultural para comprender el cambio en educación: Lecciones de un caso de estudio histórico de liderazgo en una escuela irlandesa

\section{Gerardine Neylon $^{\alpha}$ and Tom O'Donoghue ${ }^{\beta}$}

Reception date: $17 / 04 / 2020$ - Acceptation date: 22/07/2020

Abstract. This paper reports a research project undertaken whose aim was to explore the possibility of using a particular theoretical framework for engaging in preliminary studies aimed at analysing specific historical instances of change in education. The change that was the focus of the investigation was a new school established by the Sisters of Mercy in Ennis, County Clare (Ireland), to replace an original school built in 1865 . This was no 'ordinary school. Instead, it was at the time deemed a model infant and primary school. While the case is of interest in its own right, the principal aim of the study was to explore the potential of cultural activity theory for engaging in historical analyses of cases of its type and using its structure, the CHAT model, as a framework for presenting results.

Keywords: Cultural Historical Activity Theory (CHAT); catholic schooling; Ireland.

\footnotetext{
a Graduate School of Education. The University of Western Australia. The University of Western Australia (M428), 35 Stirling Highway, 6009 Perth, Australia. gerardine.neylon@uwa.edu.au (D) https://orcid.org/0000-0002-6805-0528

B Graduate School of Education. The University of Western Australia. The University of Western Australia (M428), 35 Stirling Highway, 6009 Perth, Australia. tom.odonoghue@uwa.edu.au. (D) https://orcid.org/0000-0003-3760-6869
}

How to cite this article: Neylon, Gerardine and Tom O'Donoghue. "Exploring the potential of cultural historical activity theory for understanding change in education: lessons from a historical case study of leadership in an Irish school". Historia y Memoria de la Educación 13 (2021): 675-695 
Resumen. Este artículo da cuenta de un proyecto de investigación realizado cuyo objetivo fue explorar la posibilidad de utilizar un marco teórico concreto para realizar estudios preliminares dirigidos a analizar instancias históricas especificas de cambio en la educación. El cambio que fue el foco de la investigación fue una nueva escuela establecida por las Hermanas de la Misericordia en Ennis, Condado de Clare (Irlanda), para reemplazar una escuela previa construida en 1865. No fue esta una "escuela ordinaria»; por el contrario, en ese momento se consideró un modelo de escuela infantil y primaria. Si bien el caso es de interés por derecho propio, el objetivo principal del estudio fue explorar el potencial de la teoría de la actividad cultural para enfrentarse al análisis histórico de casos de su tipo y utilizar su estructura, el modelo CHAT, como marco para presentar resultados.

Palabras claves: Teoría de la Actividad Histórico-Cultural (CHAT); escolarización católica; Irlanda.

\section{INTRODUCTION}

In recent years, and particularly with the development of cultural history, ${ }^{1}$ historians of education have begun to adopt a wider variety of theoretical approaches in their work than previously. One approach not drawn upon extensively, however, is that of Cultural Historical Activity Theory (CHAT), even though academics have used it widely in other domains of education research and in relation to social services provision. ${ }^{2}$ This situation is to be lamented given its potential for identifying and illuminating broad sweeps of change in education at local, national and international levels. Before examining how it can be used to this end, however, a valuable preliminary step, we hold, is to draw on it to study particular historical events. We offer this paper as one contribution to promote dialogue on the matter.

The paper arose out of cogitating the following question. Given that research literature for the period 1940-1965 indicates that nuns in Ireland who became teachers underwent a strict formation regimen intended to prepare them for total obedience to their superiors, inculcate in them a non-questioning attitude and deprive them of opportunities to take

\footnotetext{
1 Allesandro Arcangeli, Cultural History: A Concise Introduction (London: Routledge, 2011).

2 Kirsten A. Foot, "Cultural-historical activity theory: Exploring a theory to inform practice and research", Journal of Human Behaviour in the Social Environment 24, n. ${ }^{\circ} 3$ (2014): 329-347.
} 
initiative, ${ }^{3}$ how did they fare on assuming leadership positions in schools? One way of addressing this question, we hold, is to engage in a series of related case studies on the activities of particular nuns who became principals. To do so, of course, requires that one adopt an appropriate theoretical framework for the task. CHAT, we contend, constitutes one possibility in that regard. Recognising this, we sought to investigate how researchers might use it to examine one particular case. The one we chose was where a Sisters of Mercy' nun who had been trained in compliance had, after becoming superior in her local convent in Ennis, County Clare, the capacity to lead and be a change agent in relation to an infant and primary school built in the town. Both locals and national educationists heralded it as being a model infant and primary school when it opened in 1965.

The paper is in three parts. First, we outline the general context, including the stereotype of the approach of female religious in Ireland to infant and primary school education from the advent of national independence in 1922 until the mid-1960s. An exposition on the CHAT model and on its potential for conducting investigations on particular cases in the history of education, including in Ireland, follows. The third part of the paper then reports the results of the use of the CHAT model to investigate the school-building project in Ennis.

\section{THE BACKGROUND}

From the middle of the 19th century, the Catholic Church controlled the vast majority of education institutions in Ireland. ${ }^{4}$ A long-established associated narrative in the history of the process of education in Catholic schooling in the nation from 1922 to 1965 is that, largely, teachers worked within an authoritarian framework. ${ }^{5}$ This meant that they promoted orderliness, careful control, direction, and the 3Rs, in an inflexible manner. Specifically in the case of primary schools operating as parish schools and those operating as religious-order run schools, the situation was

\footnotetext{
3 Thomas A. O’Donoghue, "Rescuing lay teachers in Catholic Schools from anonymity for the period 1870-1970", Educational Research and Perspectives 26, n. ${ }^{\circ}$ (2004): 78-93.

4 Thomas A. O’Donoghue and Judith Harford, “A comparative history of Church-State relations in Irish education”, Comparative Education Review 55, n. 3 (2011): 315-341.

5 Thomas A. O'Donoghue, The Catholic Church and the Secondary School Curriculum in Ireland, 1922-62 (New York: Peter Lang, 1999)
} 
made possible because they were staffed by teachers (both religious and lay) trained in Catholic teacher training colleges, and the managers were priests, religious brothers or nuns. The remainder of this section of the paper focuses on the preparation of nuns as teachers. That is because a particular community of nuns, the Sisters of Mercy in Ennis, County Clare, initiated the project considered in the final section of this paper.

Nuns in Ireland, as elsewhere, were formed for a life based on an observance of the vows of poverty, chastity and obedience. This situation, the Church held, conferred on them a special stamp. ${ }^{6}$ Specifically in relation to their role as teachers, the argument was that their religious personality, which was formed through a period of special religious training of which teacher training was an integral part, made them ideally suited for shaping young Catholic minds. Relatedly, in excluding lay teachers from the development of school policy, the standard argument of the nuns was that they themselves were eminently more suited to determining policy and administering the schools because of their religious commitment, their total devotion to their work, and the absence of distracting family demands and problems. ${ }^{7}$

Those who joined religious orders of nuns and wished to become teachers underwent a process of formation in which their professional training and their spiritual training were interleaved. The first stage of formally joining was by becoming a postulant. This represented a break with the past and was usually of 18 months' duration. On their first day, postulants partook in a religious ceremony at which they received a distinctive dress and neat veil. 8 In some religious orders, they then underwent a crash course in very basic primary school teacher training for four to six weeks, including lectures on how to teach mathematics, reading and spelling.

A postulant learned to live according to the rhythms of the community. ${ }^{9}$ Normally she rose at 5:30 a.m. for Mass, followed by breakfast with the full

\footnotetext{
6 O’Donoghue and Harford, "A comparative history".

7 O’Donoghue, "Rescuing lay teachers in Catholic schools".

8 Ann Power, The Brigidine Sisters in Ireland, America, Australia and New Zealand, 1807-1922 (Dublin: Four Courts Press, 2018).

9 Thomas A. O'Donoghue and Anthony Potts, A. "Researching the Lives of Catholic Teachers who were Members of Religious Orders: Historiographical Considerations", History of Education 33, n. ${ }^{\circ}$ 4 (2004): pp. 469-481.
} 
community, before heading off to school with some of the nuns. Here she taught until about 3:30 p.m. She then had to return to the convent for community prayers at 5.00 p.m., followed by tea and "recreation", the latter usually referring to a period of time when those who were teaching marked pupils' work and prepared some lessons for the following day. In these ways, the order to which she belonged eased her into its rhythms.

Postulants listened at mealtime to spiritual writings read out by a community member. This was a time when they learned about what was termed the spirit of the order, about the life of the founder or foundress, and about the heroic deeds of the early members who had established convents, monasteries, schools and hospitals. Those responsible for their direction also moulded them into a state of single-mindedness, allowing no reading for pleasure or listening to the radio.

Postulants who stayed the course continued by becoming novices. The novitiate, which usually lasted two years, commenced with a formal reception into the religious order. Henceforth, one wore the full religious dress. The first year, called the canonical year, aimed at promoting a deep spiritual awareness in the novices. The focus was on the nature of religious life and on living according to the vows of poverty, chastity and obedience. This took place through a combination of lectures and reading, conducted within the framework of a highly structured timetable overseen by a novice mistress. These individuals whose job it was to test and discern the vocation of the novices were usually very rigid. They gave instruction in the rules of the order, impressed that one had to accept these without question, and promoted practices aimed at detaching one from possessions.

The second year of the novitiate was usually a teacher-training year. Within their orders' teacher training colleges, frequented also by female lay students, novices spent some time studying the substantive content of the subjects on the State-prescribed curricula, particularly Irish, English, mathematics, history and geography. Most of the emphasis, however, was on teaching methods. Further, they spent periods of time observing ordinary lessons, observing lessons being taught by a master of method and taking classes in schools.

Throughout this teacher-training year, the theological and spiritual training of the novices continued, especially at weekends. The end of the 
novitiate years led to the stage of first profession to the religious way of life, the essence of which was living in the community of a religious order and leading a life of poverty, chastity and obedience. From now on, unless one decided to leave, one was an ordinary member of one's religious order, living the standard life of a member of the community, and recognizable as a typical teacher in a Catholic school.

Overall, then, it is not difficult to appreciate that the nature of the formation of the female religious teachers, coupled with the prevailing Catholic view on human nature in Ireland during the period under consideration, played a major part in the development and maintenance of an education system that was both highly controlled and highly controlling. Indeed, what operated in Catholic girls' schools was a set of practices reflecting to a certain extent the authoritarian nature of the rules and regulations of the dominant religious orders involved in education, and an intersection between these rules and the social conditions of the Irish Catholic population. ${ }^{10}$ Thus, critical debate was actively discouraged and there was a promotion of rote learning. In this way, so the standard narrative goes, the school environment presented no threat to the habitual ways in which teachers who were members of religious orders thought and acted.

It is not the purpose in this paper to contest outright the general interpretation outlined so far. There is, however, a need to recognize that those who have provided various accounts in which it appears developed them primarily from examining the constitutions of the religious congregations that elaborated on how they were to realize their shared vision, and on the books of customs that described adaptations to local circumstances. A very small number of academics, drawing on a more extensive body of sources, however, have troubled the notion that variations in relation to the general experience were relatively unknown. O'Donoghue and Harford, ${ }^{11}$ for example, asked how it was possible that teaching sisters were able to proceed to take up leadership positions, given that they had undergone a strict formation regimen intended to prepare them for total obedience to their superiors, inculcate in them a non-questioning attitude, and deprive them of opportunities to take initiative. To address this, they conducted an oral history project that involved interviewing a

10 O'Donoghue, The Catholic Church.

11 O’Donoghue and Harford, "A comparative history". 
group of nuns who had worked as school principals in Ireland during the 1950s and 1960s. The results led them to propose that, contrary to what is usually portrayed, a significant amount of freedom of thought and action had been made available to some of their informants, particularly once they progressed from being novices, and that this stood them in good stead when they went on to become sister principals.

Further troubling of this nature is required in order to bring more nuance to the understanding of the work of nuns as school principals in the history of education in Ireland. One way to do this is to adopt the standard scientific approach of seeking out negative cases and then analysing them systematically. It was to that end that we conducted the case study reported later in this paper. While the phenomenon investigated is of interest in its own right, the principal aim of the study was to explore the potential of cultural activity theory for engaging in historical analyses of cases of its type and using its structure (the CHAT model) as a framework for presenting results.

\section{THE CHAT MODEL}

The evidence available on the school-building project in Ennis reported on in the next section, reveals that a multitude of influences came to bear on it in intricate patterns and configurations. At the most basic level, these can be described. At a more sophisticated level, on can relate relationships to the socio-political circumstances prevailing at the time in an attempt to contextualise them. More demanding still is to try to combine these two approaches in seeking to uncover the dynamics of change and transition relating to what happened and to how it was able to happen. The CHAT model was very helpful in this regard.

From the outset, it is necessary to make clear we subscribe to a view that, when using the CHAT model, one can simultaneously subscribe to the interpretivist-constructivist research paradigm. This is to hold to a position that while there is, and has been, a real world out there (including countries, education systems, transitions, changes) that we are able to study, the meanings one attaches to it are not independent of oneself as researchers. Rather, one has to either discover it or create it for oneself ${ }^{12}$

12 Thomas M. Duffy and David H. Jonassen, "Constructivism: New implications for instructional technology?”, Educational Technology 31, n. ${ }^{\circ}$ 5, (1991): 7-12. 
through a process of interpretation. Further, an interpretivist-constructivist research approach is also compatible with the CHAT model in that it aims at understanding the complexity of the topic under investigation.

The CHAT model itself provides lenses for understanding human cognition by examining the dialectical relationships among people, tools, and goals as they influence and are shaped by social structures, culture, and history within the context of a community. ${ }^{13}$ It deems an activity system to be the primary units of analysis. This consists of networks of sociocultural elements, with complex mediational structures, that shape the collective actions of individuals who are motivated to achieve a goal. ${ }^{14}$

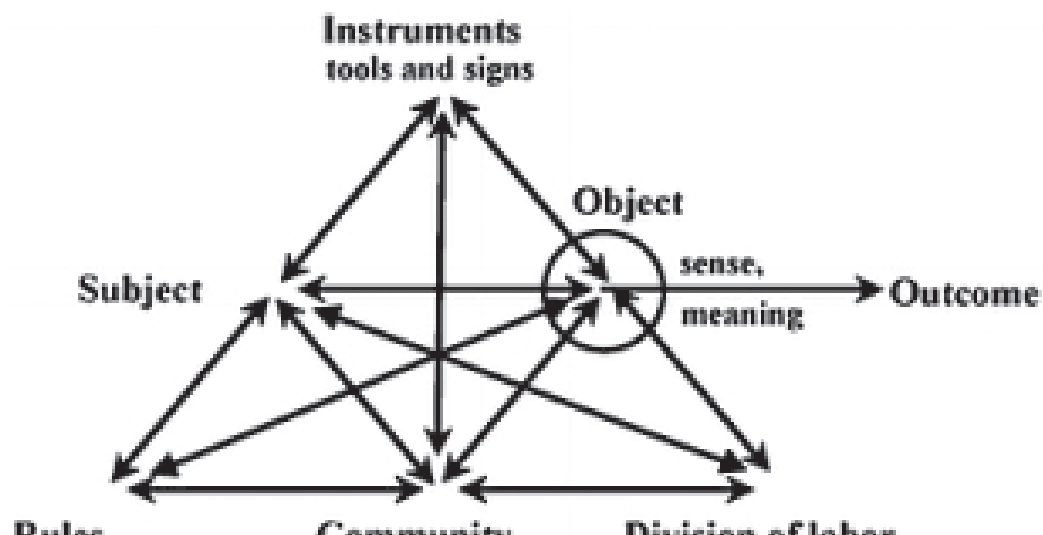

Rules

Community

Division of labor

Figure 1: The Basic CHAT Model.

The common elements within an activity system are object, outcome, subject, tools, rules, community and division of labour (see figure I above).

There are various accounts of the historical background that led to the generation of the CHAT model. The general view, however, is that it originated in the activity theory of Vygotsky and evolved through a

\footnotetext{
13 Yrjö Engeström, Learning by Expanding: An Activity/Theoretical Approach to Developmental Research (Helsinki: Orienta-Konsultit, 1987).

14 Yrjö Engeström, "Activity theory as a framework for analysing and redesigning work", Ergonomics 43, n. 7 (2000): 960-974; Aleksie Nikolaevich Leontiev, Activity, Consciousness, and Personality (Englewood Cliffs, NJ: Prentice-Hall, 1978).
} 
number of generations, with a major strand being that developed by Leontiev and Engeström. ${ }^{15}$

Each community also has a set of collectively negotiated rules, or sociocultural conventions. These conventions are either explicitly stated or implicitly understood guidelines for acting, behaving, and interacting within the community. They provide lens for understanding how to become a full participant in a community.

\section{ANALYSIS}

\section{Regarding the object of the vision}

The object in the CHAT model is founded on Vygotsky's ${ }^{16}$ and Leontiev's ${ }^{17}$ idea of object-oriented action. On this, Leontiev ${ }^{18}$ claimed that human action is structured, motivated, and directed by an external object. This object is the target or product of the activity system. Objects generally surface to meet a human need ${ }^{19}$ and studying them provides insight into why people perform different actions.

The object in this case study was the new school sought by the Sisters of Mercy in Ennis. Their desire for a school was hardly surprising at the time given that the existing one was nearly 100 years old. What was surprising, however, was the nature of the structure of the school envisaged by the nun who steered the project.

By way of background, it is instructive to keep in mind that the overall stock of primary schools in Ireland at the time was in poor condition..$^{20}$ Additionally, about two-thirds of them were small one-and two-teacher

\footnotetext{
15 Anna Stetsenko and Igor, M. Arievitch, 'The Self in Cultural-Historical Activity Theory', Theory and Psychology 14, n. 4 (2004): 475-503; Lisa C. Yamagata-Lynch, Activity Systems Analysis Methods: Understanding Complex Learning Environments (Dordrecht: Springer, 2010), 24.

16 Lev. S. Vygotsky, Mind in Society: The Development of Higher Psychological Processes. (Cambridge, MA: Harvard University Press, 1978).

17 Leontiev, Activity, Consciousness, and Personality.

18 Leontiev, Activity, Consciousness, and Personality.

19 Engeström, "Activity theory as a framework for analysing and redesigning work".

20 Government of Ireland. Investment in Education: Report of the Survey Team Appointed by the Minister of Education in October 1962 (Dublin: Stationery Office, 1965).
} 
schools. In a great many cases, it was school managers in the middle-tolate $19^{\text {th }}$ century who had most of these buildings and those of quite a number of larger schools, erected. Further, about 2,000 small schools were deficient in facilities, lacked good sanitary arrangements and drinking water, depended largely on open fires for heating and, in many cases did not even have electricity. Additionally, the Department of Education deemed 1,005 primary schools across the land to be obsolete.

The Sisters of Mercy infants-and-primary school in Ennis in the late 1950s was not in the obsolete and poor-condition category. Nevertheless, it was relatively spartan, as were many of the larger urban schools in the nation. The Sisters had established their convent in the town in 1854, and had opened their original infants-and-primary school in 1865; they had had the building erected at a cost to the order of $£ 1,000$.

In 1954, the centenary of the foundation of the convent in the town, the Department of Education sanctioned a grant of $£ 176$ towards plastering the rear wall of the school. This was the first ever government grant awarded to it for structural maintenance. A condition of the State regarding acceptance, was that the nuns would take steps to obtain a site for a new school and cooperate with the Department in having one built. Following they agreeing to this, the religious community identified a five-acre field in Station Road. It then negotiated with the owners, the Quinn family, and in November 1958, it purchased the site for $£ 4,400.00$.

The eventual outcome, the new school, was exactly what the religious superior, Sr. Lelia McKenna, had envisaged. She had come back from California in 1959, having spent time there establishing a convent. During her period in America, she visited various education institutions and the experience led to her creating in her mind an image of a school that would be bright and airy, with all the classrooms facing south and that would be of good proportions, with each classroom being self-contained with bathroom and cloakroom attached. In order to maximise the financial resources available to her she negotiated in 1966 with a Mr. M. F. Casey a Paper and twine merchant, who offered to pay $£ 1,000$ for a community-owned now derelict orphanage in which in previous decades they had also housed a separate school for the children living there. 
Eventually, he purchased it for $£ 1,300$ and went on to use it to store printing and wholesale materials.

\section{Regarding the outcome of the vision}

On 31st August 1965, a reporter from The Cork Examiner, after visiting Ennis' new Holy Family School, described it as "the school they will be copying in 20 years' time". It had opened its doors eight months previously, on 7 January 1965, to a student population of 1,000. Not only did they have access to a two-story warm, bright and spacious establishment housing 25 classrooms, with large playgrounds located alongside, attached to each was a cloakroom with bench seating and a shoebox for each child. Adjoining each cloakroom were two toilets and two washhand basins with hot and cold water provided.

A new experience for students from the old school was the central heating system. There was also an assembly hall large enough to hold 550 people. It had an orchestra pit and excellent acoustics, something that the architects and builders had under instruction, taken great care to ensure. It also had a large stage with heavy blue curtains with bold tassels. It was not long before the local Franciscan Musical Society was availing of these facilities to perform an annual light opera. Within a short time also, students formed a band, learned the Ó Riada Mass in Irish and performed around Munster in various competitions.

Another new experience for students from the old school was that all had to purchase a pair of slippers, as wearing shoes on the new shiny floors was forbidden. Twelve of those who were amongst the first cohort to enrol as beginning students in the new school remember that vividly in conversations with the first-named author. They also recalled that a local draper was so overwhelmed with customers that he had had set up a table outside his shop solely for the selling of slippers. Parents visiting the school were also greeted with a no stilettos sign. The highly polished tiles stretching across the first and second floor corridor had a narrow red stripe on each side and students had to walk only on one stripe when going one way and on the other stripe when walking the other way. Furthermore, the first ten minutes of each day was spent by the students polishing the tiles by placing their feet into blanket bags made of old blankets and skating up and down the corridors. 
Along with the usual religious emblems that usually adorned the interior of Catholic schools at the time, each of the 25 classrooms was equipped with features allowing for the instalment of a TV and radio. Further, attached to each was a cloakroom with bench seating and a shoebox for each child. Adjoining each cloakroom were two toilets and two wash-hand basins with hot and cold water provided. A novel feature of the high quality classroom furnishing was the relationship of its size to the age group of the children occupying the classroom in which it was located.

Four chalets housed the infants' classes were true to Kindergarten design principles including sand pits, manipulative toys and even decorative designs of animals on the tiled flooring all superbly decorated with doors opening out to the playground. The tiny desks here for those in the higher grades had Tamarind tops with underneath case storage and matching grey/brown seats whose backs were 16 inches high. ${ }^{21}$ Philips and Johnston's large wall maps of Europe and the world, along with physical geography and political geography maps of Ireland and of England and Wales, each fitted with cloth extension strips, hung on the walls

The principal of the school was able to communicate with all in each of the 25 classrooms by using an intercom system each day after a child had rung the school bell. Special cookery kitchens were available with formica laminate tables at which children could work in groups of four. The provision of fridges, ovens and the latest baking equipment also constituted another exceptional feature of the school. Additionally, there was a separate spacious cafeteria with a full kitchen and dining tables.

Overall, the new school had the look and feel of a building from California. It had a cream pebbledash finish and south facing windows and doors on the ground floor that opened onto the playgrounds. One classroom on the second floor had a balcony that was used for outdoor assembly.

\section{Regarding the Subjects}

A subject can be an individual or a group. Further, unique contextual conditions facing him, her or their group can enable and constrain his,

21 Metal Utilities (1 January 1964) Invoice [Invoice for furniture] XE/202(152) Mercy Congregational Archives. Catherine McAuley Centre., 3 Herbert Street, Dublin. 
her or their activity system. These can include the historical epoch and environment, on the one hand, and individual forces such as birth, gender, sex, and temperament, on the other. As subjects, they are motivated to transform objects into outcomes, or desired results. ${ }^{22}$ Additionally, as subjects pursue the object, their identities and knowledge are shaped and transformed through their interactions with the other elements in the activity system.

From the account so far, it is clear that, in the sense defined above, foremost amongst the subjects was the Sisters of Mercy community of nuns in Ennis. It was they, especially through Sr. Lelia whose original vison it was, who articulated and promoted the concept of the new school. Others, as outlined below, embraced this vision. These included the local bishop, local clergy and local lay people. Strictly speaking however, these were followers of those subjects who initiated the project.

Sr. Lelia was in fact, positioned within a branch of the Mercy Sisters that was most unusual in Ireland, having a large number of connections nationally and internationally, unlike most other branches that existed in isolation or had just one or two other convents connected and they were primarily located in Ireland. Conversations between the firstnamed author of this paper and current members revealed that between 1872 and 1878, 45 sisters went from Ennis on missions overseas. They went to Meriden and Middletown in Connecticut, USA, to Christchurch, New Zealand and to Singleton, Australia. Around the same time, they established a number of branches also in other parts of Ireland. Then in 1959, they opened a convent in Lemoore, California, followed by one at Arroyo Grande, California in 1963. All of these developments resulted in the development of a culture within the mother house in Ennis in which a tradition of innovation, adventure, and leadership was an innate part.

\section{The Contexts of the Actions Taken (Community, Division of Labour, and Rules)}

Within the CHAT model, the contexts within which actions take place are those of the community, division of labour, and rules. The community refers to the group of individuals with a shared interest or culture that

22 Engeström, Learning by Expanding. 
interact within an activity system. The members of the community negotiate the division of labour and the rules for participation within it. Specifically regarding division of labour, the CHAT model recognises that individuals enact different roles within a community since a single individual does not have all of the knowledge and skills necessary to carry out all actions within the activity system. Furthermore, individuals participate in different roles based on their skills, knowledge, and interest.

\section{Community}

The concept of community which has been used extensively so far to refer to the religious community of Mercy Sisters in Ennis, is one used by groups of religious to refer to themselves. It so happens that its particular use in this context corresponds with the concept as used within the CHAT model, namely, as referring to all people who share the same goals. To be more particular, in the case of the Ennis school project, community in the CHAT sense consisted, at the local level, of the Ennis community of the Sisters of Mercy, the Bishop of the Diocese of Killaloe in which the school was situated, the priests of the Parish of Ennis, and the parishioners. As in many Catholic parishes in Ireland, these personnel had worked together for over a century to provide primary school education for the local Catholic children. Relatedly, they regularly worked together to maintain the physical infrastructure of the local schools, promote religious events, and raise funds for the wider Catholic community, including for those priests, brothers and female religious working on the foreign missions, especially in Africa.

The notion of the Catholic community as it applied throughout Ireland also had an international dimension. This was partly because of the international dimension of the Church itself and the spiritual bonds deemed to exist between all of the faithful regardless of where they lived. It also, however, had a more tangible dimension; Irish priests, religious brothers and nuns, through their work amongst the Irish diaspora and on the foreign missions, through spending time abroad establishing schools and parishes, and in the case of some by the early 1970s, that studying overseas for periods of time, had built up relationships that were mutually valuable. This was manifest in the case of the school in 
Ennis in both the moral and financial support given to the Sisters of Mercy by the parishioners from Lemoore, in the central valley of California, where Sr. Lelia, as noted already, had established a convent. The nature and importance of that support are considered below.

There was also nothing unusual about this reciprocal support. On this matter, O'Donoghue and Harford ${ }^{23}$ have reported that many of the Irish female religious they interviewed indicated they had formed a view before entering a convent that once they became postulants they would be members of an international family made up of fellow religious. Knowledge of the extent to which members of the community were involved in work like theirs across much of the world had been very interesting for them and served, they said, to reinforce their commitment to being engaged in an enterprise in the Roman Catholic tradition where the fundamental concern was with love, care and education.

\section{Rules}

As detailed already, each community (in the CHAT sense) has a set of sociocultural rules and conventions that are either explicitly stated or implicitly understood and that provide guidelines for acting, within the community. This concept helps one understand how bonds built up through practices of various members of the particular extended school community in Ennis over many decades in relation to school provision were such that while the nature of the new school came as a surprise in terms of its sophistication, mobilization to bring it to fruition met with no resistance. Rather, the conventions that existed resulted in the machinery of cooperation kicking into action as part of the regular rhythms in the normal functioning of parish life in Ireland legitimated through appealing to religious belief and sentiment.

Bishop Rodgers, the Bishop of Killaloe, initiated the task of raising finance to fund the building of the school when he launched what was termed an offertory promise campaign in the parish. On this, he adopted a strategy that had become common since the mid-1960s, namely, issuing a letter to all parishioners explaining that the Second Vatican Council had clearly enunciated the principle of the total commitment of the

${ }_{23}$ O’Donoghue and Harford, "A comparative history". 
laity to the work of the Church. Such commitment required, among other things, he declared, that all lay people display an active and practical interest in the affairs of their parish, and a willingness to co-operate in promoting the spiritual and temporal welfare of each other. Clearly, there was no questioning of the notion that contributing to the provision of a new school under the management of the Sisters of Mercy was central to what this commitment meant at the local level.

What did create a problem that had to be surmounted were the rules of the Department of Education relating to the provision of financial grants for the building of new schools. Officially, the Department did not have any leeway in relation to the amount that it could provide and the conditions that the recipients needed to fulfil. As indicated later, the rules in the sense of those that bound the community (in the CHAT sense) together, had to be drawn upon to overcome those bureaucratic rules of the Department of Education in order for Sr. Lelia and her fellow nuns to realise the new school they envisioned.

\section{Division of Labour}

Division of labour in the CHAT model refers to the organisation of the division of tasks amongst its members. To put it another way, 'division of labour' refers to the work, or the goal-directed or the object-directed action divided between, and conducted by, people belonging to the community. The concept also makes it possible to distinguish between collective activity and individual action, including with respect to transformations brought about.

Sr. Lelia was clearly the driving force behind the project. She took the initiative at all times, guiding all of the activity from conception to realisation. She was successful in persuading Bishop Rodgers to support her in her endeavour. He, in turn, was then able to enlist the support of the parish priests and his curates in mobilising key lay people in making regular financial collections from parishioners so that the shortfall in money from the State would be available for the completion of the school.

In parallel, Sr Lelia managed to enlist the support of Monsignor O'Doherty, parish priest of Lemoore, California, where, as mentioned 
previously, she had established a convent, while spending some time living and working as a nun in the USA. In fact, the monsignor came to Ireland in August 1960 and gave the nuns a promise that he would raise money to assist in the project. Once the building of the school was completed, he also bought various pieces of equipment for the classrooms and the hall.

The final set of individuals involved in the project were the architect, the building contractor and the workers. The Sisters of Mercy sought quotations and subsequently oversaw the awarding of contracts. The actual building work, once it started, lasted for two years, during which over 100 local men had constant employment, thus amplifying local community association with the school.

\section{Regarding the Tools or Mediating Artefacts}

Tools or mediating artefacts ${ }^{24}$ constitute another central point in the triangle that constitutes the CHAT model. Here what is being advanced is a notion that such cultural artefacts as language and signs function as intermediary aids that the acting subject chooses to use when trying to attain the goals of his or her actions.

Essentially, tools can be internal or psychological tools (mental models and symbols constituting cognitive strategies used to master higher mental functions) that can be deeply embedded within the elements of the activity system. Further, when the subject selects a tool to use, the tool defines the way the subject carries out an action. Equally, the subject often shapes and enhances the tool to make it more effective and useful. This, in turn, can then change the way the subject completes a task

Subjects used tools in two principal ways in order to advance towards having the school in Ennis built. The first of these was when Sr. Lelia invoked local political allegiances on being informed that the type of school she sought was more grandiose than that approved by the Department of Education and, hence, would be disqualified from receiving a State building grant. What we are referring to here is political activity

24 Vygotsky, Mind in Society. 
that is more evidently concerned with addressing the immediate needs of the local electorate than with strategy that might affect the national interest.

The plans drawn up by the architect on the instructions of Sr. Lelia far exceeded the standard size allowed by the Department of Education. Almost immediately, she approached a local Fíanna Fáil member of government, Dr. Paddy Hillary, who also happened to be the minister of education at the time. In her letter to him she argued that the maximum of 11 sq. feet per child allowed by the Department would make it difficult to place a black board, that desks would be have to be put too close together, and that teachers would not be able to walk freely around the classroom or provide drama classes. She then appealed to his sense of duty, requesting that he think about the standard of living of the children that, as she put it, ought to be much higher than the standard known to themselves. She added a subtle appeal to his religious convictions by signing off the letter as $J C$. This, presumably, was a suggestion that she was appealing to him in a perceived role as the handmaiden of Jesus Christ.

Sr. Lelia was no stranger to politics and had participated in assisting an Anti-treaty rebel operative Liam Mellows avoid capture in 1916 by lending him her habit. This he wore in a dashing escape to England disguised as a nun. The veil is now in the National Museum of Ireland, Sr. Lelia herself having donated it in 1941.25

The strategy adopted by Sr. Lelia's worked. The Department of Education, following the intercession to the Minister, agreed to pay $£ 218,000$ of the total cost, which was the amount it would have paid if the nuns had followed the original specifications laid down by the Department. The additional cost in order to ensure that the more impressive school sought became a reality was $£ 80,000$. Members of the parish raised this money.

This brings us to the second strategy, which was the brainchild of Bishop Rodgers. He drew on the new thinking within the Catholic Church following the proceedings of the Second Vatican Council

\footnotetext{
25 National Museum of Ireland 2015 https://thecricketbatthatdiedforireland.com/2015/08/29/nuns-
} veil-liam-mellows-on-the-run-1916-rising/ 
(1962-65) on the importance of the laity becoming deeply involved in parish life. The parish of Ennis, he opined, was the ecclesiastical centre of the Diocese of Killaloe, and he thanked God that it had progressed and developed in a remarkable manner in recent years. Now, however, he went on, this situation had made further important and urgent commitments a matter of absolute necessity. Central in this regard was ensuring that the parish come up with its financial contribution to the cost of building the school.

The bishop launched what he termed a planned giving programme. Through it, he asked parishioners to examine their consciences and ask themselves how much they spend on luxuries. Then, he said, each should decide how much he or she should give to the programme. Further, he encouraged all to commit themselves as quickly as possible to their decision as otherwise they might change their minds.

All of this beseeching was located within a religious paradigm. In particular, the bishop promoted the notion of the promise required as a forthright expression of attitude towards 'the faith.' Along with the spiritual value in the practice for the individual, he said, one would also gain great satisfaction to the giver psychologically. To this, he added the social justification that 'promising' would enable the parish to have all of the advantages of planning that one would never consider denying one's own affairs.

\section{CONCLUSION}

The CHAT model has been used effectively to analyse change in various aspects of society, including in the sphere of education. ${ }^{26}$ This is because of its focus on how the nature of actions is constituted socially, culturally, historically and educationally. On this, Yamagata-Lynch ${ }^{27}$ argued for its use to help identify the boundaries of such complex systems as the socio-political and educational transformation in a particular country and of its education system. We add to this a view that such a position is helpful not only in studying contemporary change but also in

\footnotetext{
26 Engeström, Learning by Expanding.

27 Yamagata-Lynch, Activity Systems Analysis Methods, 24.
} 
studying change historically, and in relation to specific developments as well as broader societal ones.

The CHAT model has enabled us to examine how practices used by Sr. Lelia to establish the new infants-and-primary school in Ennis help to contest the received view that nuns trained in Ireland prior to the deliberations of the Second Vatican were incapable of engaging in activities aimed at ensuring children could have creative and stimulating school experiences. This was at a time before principals who were nuns began to adopt systematic approaches to improving their skills for their position. It was also before they began to meet on a regular basis with peers from other communities of nuns to see what they could learn from each other. Cogitating this opens up possible avenues for further investigations. To this end, the CHAT model, we feel sure, will continue to be of great assistance.

\section{Note on the authors}

Gerardine Neylon is a political scientist specialising in Early Childhood Education and Care (ECEC). She lectures in policy and pedagogy at the Graduate School of Education, in The University of Western Australia. She is leading a research project on Graduate teachers, educators and children's perspectives on the implementation of the principles and practices of the Early Years Learning Framework (EYLF) as demonstrated through a nature-based pedagogy approach.

Tom O'Donoghue has a personal chair in history of education at The University of Western Australia. He is an elected Fellow of the Royal Historical Society (UK) and of the Academy of the Social Sciences in Australia. His research focus is on the historical antecedents to contemporary education problems and issues.

\section{REFERENCES}

Arcangeli, Allesandro. Cultural History: A Concise Introduction. London: Routledge, 2011.

Duffy, Thomas M., and Jonassen, David H. "Constructivism: New implications for instructional technology?”. Educational Technology 31, n. ${ }^{\circ} 5$ (199): 7-12. 
Engeström, Y. Learning by Expanding: An Activity/Theoretical Approach to Developmental Research. Helsinki: Orienta-Konsultit, 1987.

Engeström, Y. "Activity theory as a framework for analysing and redesigning work". Ergonomics 43, n. ${ }^{\circ} 7$ (2000): 960-974.

Foot, Kirsten A. "Cultural-historical activity theory: Exploring a theory to inform practice and research". Journal of Human Behaviour in the Social Environment 24, n. 3 (2014): 329-347.

Government of Ireland. Investment in Education: Report of the Survey Team Appointed by the Minister of Education in October 1962. Dublin: Stationery Office, 1965.

Harford, Judith and O'Donoghue, Thomas A. "Continuity and change in the perspectives of women religious in Ireland on themselves both as religious and as teachers in the years immediately prior to, and following, the Second Vatican Council (1962-65)". Paedagogica Historica 47, n. 3 (2011): 399-413.

Leontiev, Aleksie Nikolaevich. Activity, Consciousness, and Personality. Englewood Cliffs, NJ: Prentice-Hall, 1978.

Metal Utilities (1964, January 1) Invoice [Invoice for furniture] XE/202(152) Mercy Congregational Archives. Catherine McAuley Centre., 3 Herbert Street, Dublin

National Museum of Ireland 2015 https://thecricketbatthatdiedforireland. com/2015/08/29/nuns-veil-liam-mellows-on-the-run-1916-rising/

O'Donoghue, Thomas A. The Catholic Church and the Secondary School Curriculum in Ireland, 1922-62. New York: Peter Lang, 1999.

O’Donoghue, Thomas A. "Rescuing lay teachers in Catholic Schools from anonymity for the period 1870-1970”. Educational Research and Perspectives 26, n. 2 (2004): 78-93.

O’Donoghue, Tom and Harford, Judith. "A comparative history of Church-State relations in Irish education”. Comparative Education Review 55, n. ${ }^{\circ} 3$ (2011): 315-341.

O’Donoghue, Thomas A. and Potts, Tony. "Researching the Lives of Catholic Teachers who were Members of Religious Orders: Historiographical Considerations". History of Education 33, n. ${ }^{\circ} 4$ (2004): 469-481.

Power, Ann. The Brigidine Sisters in Ireland, America, Australia and New Zealand, 1807-1922. Dublin: Four Courts Press, 2018.

Stetsenko, Anna and Arievitch, Igor. M. "The Self in cultural-historical activity theory”. Theory and Psychology 14, n. 4 (2004): 475-503.

Vygotsky, Lev S. Mind in Society: The Development of Higher Psychological Processes Cambridge, MA: Harvard University Press, 1978.

Yamagata-Lynch, L. Activity Systems Analysis Methods: Understanding Complex Learning Environments. Dordrecht: Springer, 2010. 